\title{
FACTORS AFFECTING THE DECISION TO SHOP ONLINE VIA E-COMMERCE PLATFORMS IN VIETNAM
}

\author{
CUONG NGUYEN ${ }^{1}$, TOAN DO ${ }^{2}$ \\ ${ }^{1}$ Industrial University of Ho Chi Minh City \\ ${ }^{2}$ University of Greenwich \\ nguyenquoccuong@iuh.edu.vn,toando2688@gmail.com
}

\begin{abstract}
The purpose of this study is to develop a better understanding of factors affecting online shopping behavior via e-commerce platforms among Vietnamese consumer. The survey was conducted online by 346 consumers in Vietnam to test the proposed conceptual model of online shopping intention using multiple regression analysis. The research methodology used in this study is combining TAM and TPB (C-TAM-TPB). The results support all proposed hypotheses. Perceived Usefulness, Perceived Ease of Use, Perceived Risk, Social Influence and Awareness of Behavior Control are the factors that have direct impacts (positive and negative) on online shopping decisions of Vietnamese consumers via e-commerce platforms. Based on the findings, business managers can have a better understanding of online shopping behavior of Vietnamese consumers. Especially, e-commerce marketers should develop strategies to promote customers' purchasing decisions among Vietnamese consumers. There is positive evidence to show that Vietnamese e-commerce platforms have enormous potentials for development; meanwhile, the ecommerce industry in Vietnam are becoming more competitive. The findings of this study are expected to help marketers and businesses remain competitive via proposed managerial implications.
\end{abstract}

Keywords: Internet Shopping Decision, E-commerce platforms, C-TAM-TPB model, Vietnamese consumers.

\section{INTRODUCTION}

The development of the internet in the world is very fast in recent years, in which online transactions show positive growth [1]. Online shopping and the e-commerce industry are booming worldwide. The Internet helps not only businesses but also everyone to communicate anywhere and anytime [2]. According to Satista [3], the proportion of sales of e-commerce accounts for $10.2 \%$ of the total retail sales of the world; experts also predict this rate in 2021 will continue to increase to $17.5 \%$. It is remarkable to see the effectiveness of applying technology into online transactions; consumer behavior changes with the impact of technology [4]. The modern technology platform is the basis for researchers to predict a positive future for online commerce or e-commerce in recent years. Since joining the World Trade Organization, foreign investors have invested in many fields including the internet and e-commerce in Vietnam. Prospectively, it is a good infrastructure for Vietnam's development in the e-commerce industry. It can be said that technology plays an important role in e-commerce[4],[12]. According to the Ministry of Information and Communications in Vietnam, there is up to 54\% of people use the internet, which is higher than the global average of only $46.5 \%$. According to EVBN [5], the average income of Vietnamese people is expected to increase with the fastest rate in ASEAN from 2012 to 2020. Vietnam's development prospects can be used to analyze the opportunities of businesses in this area [6]. The objective of this study is to identify the factors that influence the intention of online shopper via e-commerce platforms in Vietnam. Furthermore, this study aims to assess the relationship between main factors that lead to purchase online activities through e-commerce platforms in Vietnam and suggests solutions for developing Vietnamese e-commerce industry.

\section{LITERATURE REVIEW}

\section{Overview of Vietnam's online retail market}

Since Vietnam joined WTO in 2007, the investment of Vietnamese enterprises and foreign investors is a solid foundation for internet development. According to [4], technology plays an important role in 
changing consumer shopping behavior. Vietnam is expected to be one of the most fast-growing ecommerce markets in ASEAN community; the average income of Vietnam is expected to increase from 12 to 33 million in the period 2012-2022 [5]. The Ministry of Information and Communications in Vietnam (2018) reported there are more than 50 million people, accounting for more than half of the population using the internet. The prospect of e-commerce in Vietnam is tremendous, in which the e-commerce penetration rate reaches $54 \%$, higher than the world average of $46.5 \%$. Businesses and sellers in the ecommerce sector need to be knowledgeable about the factors affecting customer behavior when shopping to develop appropriate strategies[6]. Remarkably, there is up to $57 \%$ of the total number of customers participating in e-commerce in Vietnam is a business; the average spending reaches \$ 145 per person [7]. The mobile phone is the most popular device used to access the internet in Vietnam, reaching 42 million and continuing to increase to 55 million by 2022[3]. According to [5], Vietnam currently has $72 \%$ of the population using smartphones, a positive signal for the potential of e-commerce development. Besides, Vietnam's GDP has a relatively stable growth rate from 2012 to 2017; experts predict that GDP will witness a strong development from 2017 to 2022 [3]. The e-commerce industry is becoming more attractive to many foreign investors in Vietnam. Currently, competition is quite intensive with a total of 13,510 ecommerce websites in 2017[7], with a significant increase compared to 9,429 websites in 2016 [8]. It shows that the potential of e-commerce attracts many businesses to participate in this field. Businesses participating in online shopping can enhance their competitiveness by improving the availability of product information, available resources, time-saving benefits or fee reduction [9].A problem noted by the Vietnam Competition Administration Department and the Ministry of Industry and Trade, there is up to $73 \%$ of customers' complaints are currently referring to the quality and reliability of products when the products they receive different from the supplier's description. This fact is one of the common problems affecting ecommerce in Vietnam; businesses should pay attention to improve the quality of their services to attract customers.

\section{The evolution of online shopping from traditional shopping in Vietnam}

Online shopping is the process in which customers buy goods, services from a seller in real time without an intermediary service over the Internet. Online shopping significantly evolved from traditional shopping. Both online shopping and traditional shopping share common features products in the shopping process such as identifying needs, finding information, evaluating and choosing, paying and responding later when buying $[10,11,12]$. Besides the common points, online shopping and traditional shopping have been influenced by different factors. Firstly, traditional shopping requires customers to go to the point of sale to be able to trade [13].Traditional shopping may consume a lot of time and efforts of consumers. However, traditional shopping helps customers choose products correctly, suitable to their needs. The process of communication between sellers and customers is a strong point of traditional shopping, and it helps customers understand the product and choose to buy products exactly what they want [14]. Secondly, online shopping can be used by customers through internet-connected electronic devices [15]. Customers can shop at any location and any time as they wish [13]. Products are available with information and images to describe customers who can better understand the product[6], [16]. With many advantages compared with traditional shopping, online shopping has gained wide acceptance of consumer [17].

\section{Factors influencing consumers' online shopping}

Cheung[18] provide a critical and comprehensive review of the theories and empirical results of consumer online behavior. The theory of planned behavior (TPB), the theory of reasoned action (TRA), and technology acceptance model (TAM) were identified as the dominant conceptual frameworks. Cheung[18]also report there are five major categories of determinants that influence consumer online behavior. The first category is consumer characteristics such as consumer demographics, attitude, motivation, perceived risk, and trust. Gong [19] report that Chinese consumers' age, income, education, and marital status, and their perceived usefulness are significant predictors of online shopping intention. The second category is product characteristics such as price and product type. Kocas [20] confirm the influence of price on customer's online shopping through the evolution of prices in electronic markets. The third category is merchants and intermediate characteristics such as brand, service, privacy and security control [17].The fourth category is environmental influences such as exposure, market uncertainty, and 
competition. Moe and Schweidel [21] confirm the impact of online product ratings and reviews on product sales; we still have a limited understanding of the individual's decision to contribute these opinions. The fifth category is medium characteristics such as ease of use and information quality. Besides, Liu [22] reports that risks are one of the most important issues when customers choose to shop online instead of traditional shopping. Recently, Ariffin [23] suggest that consumers' perceived risks when they intend to purchase online. There are five factors of perceived risk have a significant negative influence on consumer online purchase intention, while the social risk was found to be insignificant. Among these factors, the security risk is the main contributor for consumers to deter from purchasing online. From the literature review, the research methodology of this study is combining TAM and TPB (C-TAM-TPB). According to Taylor and Todd [24], C-TAM-TPB is an improved model based on the TAM model and TPB model, it overcomes the weaknesses of the models and deepens the perceptions of direct impact on online shopping behavior.

\section{Conceptual model and hypotheses}

The conceptual model of this study is built based on C-TAM-TPB model and Risk perception theory. The factors in these models are used to develop hypotheses in Figure 1.

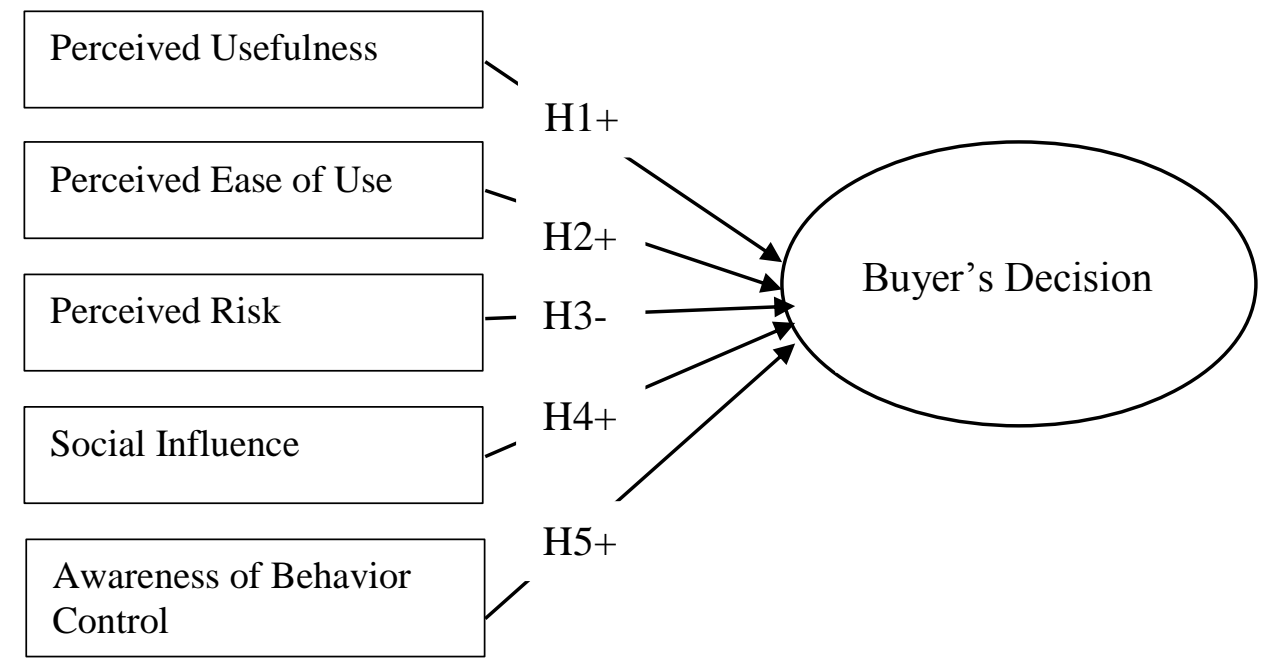

Figure 1. The proposed model

\section{Perceived Usefulness (PU)}

Technology brings benefits to business development strategies and increases profits of businesses around the world [25]. The power of consumer technology and behavior is the basis for perceived usefulness formation [26]. Perceived usefulness is an element that shows how useful technology is to customers when shopping online [27]. The usefulness is shown through fast online transactions with no waiting time [27]. Customers tend to choose to shop online because they feel more favored than traditional shopping Perceived usefulness has a direct impact on customers' buying behavior, which can be a money saver compared to traditional procurement [26]. In addition to the positive impact of perceived usefulness directly on consumer behavior, they can be influenced by other factors when shopping online[28]. Hence, the first hypothesis is stated as H1 (+): Perceived usefulness (PU) has a positive effect on the customer's online shopping decision.

\section{Perceived Ease of Use (PEU)}

Technology changes the way customers buy. Perceived ease of use is a factor that shows the ability of customers to adapt to online shopping [28]. Perceived ease of use is a factor that demonstrates customers' ability to accept technology [27] and explains easy online shopping behaviors [28].Many previous studies suggest a business to consider customer experience, including speed of service, convenience upgrades and easy access to customers [29], [30]. As customers can access and use the website quickly without any difficulties, they ten to prioritize the service that the website provides. The technology that makes it easy for customers to use will enhance the opportunity for customers to use the service when shopping online. 
Customers appreciate the utility that technology brings to them. Researching applications of technology have always been a top priority for business strategy analysts [19]. According to Gitau and Nzuki [31], perceived ease of use is an indispensable element in the TAM model, and businesses should focus to improve the potential to attract customers. The quick response of online services encourages customers to accept the service easily [32]. As a result, the second hypothesis of this study is stated as $\mathrm{H} 2$ (+): Perceived ease of use (PEU) has a positive effect on customer's online shopping decision.

\section{Perceived Risk (PR)}

Customer data security policies always play an important role in securing the reputation of companies in the e-commerce industry [33]. Many problems arise as online transactions such as the identity thefts, fraudulent attempts to hijack assets, use of unauthorized credit cards [34]. Technology helps online business transactions operate more conveniently, but there are many risks along the process. The level of network security has a strong impact on the safety of customer information[35]. As using online provider's service, online shoppers confirm a confidentiality agreement with the provider. Forsythe [30] report that perceived risks of online shopping has a negative influence on customer's decision. In many countries, the government is working closely with businesses that provide online shopping services to protect data privacy and customer confidence when shopping online [31]. In the banking sector, security issues are always a major problem hindering the intention to use the service [32] ). Heijden [33] and Ma'ruf et al. [34] both claim that perceived risk is negatively correlated with customers' online shopping intent. Recently, the security risk is the main contributor for consumers to deter from purchasing online. Therefore, the third hypothesis is stated as H3 (-): Perceived risk (PR) has a negative effect on the customer's online shopping decision.

\section{Social Influence (SI)}

Social influences can influence customer's decision making. Moe and Schweidel[21] report online product opinion from other people can have an impact on online shopper's decision. This influence leads to the final decision of the customer, and it may be the decision to perform the behavior or refuse to use the online service[35]. Social influence has a direct impact on customer behavior in the e-commerce industry [36]. Researchers also argue that social norms play an important role in consumers' attitudes toward online shopping [37]. Chin [38] confirm that social influence is significantly related to willingness to purchase online. Recently, Zhao [39] report that perceived review quality positively impacts informational influence, while perceived review quality, consistency, and social presence jointly impact value- expressive influence. Interestingly, informational influence impacts both perceived decision quality and perceived usefulness of the website, while value-expressive influence only impacts the perceived usefulness of the website. As a result, the fourth hypothesis is written as $\mathrm{H} 4(+)$ : Social influence (SI) has a direct positive effect on customer's online shopping decision.

\section{Awareness of Behavior Control (ABC)}

Behavior is considered to be individual actions and the ability to control before committing acts. In previous studies, the intention to purchase online was thought to be under the control of attitudes [40] and the availability of resources along with the ability to control behavior[24]. Some studies suggest that a positive attitude cannot fully control a customer's decision; it bases on the conditions of the surrounding environment [19]. Other factors come from outside such as selling price, the reputation of the seller, and brand value can delay the decision to purchase[19]. Seller's information can affect customer attraction if the seller has a high reputation; they will easily convince customers and vice versa. The strength of online shopping is that it is not restricted to customers' shopping capabilities, in some cases such as health problems, opening hours[41], [42]. Wang [43] confirm that knowledge is positively associated with trust and online shopping activities. In other words, people who know more about online shopping will trust and go shopping more online. Hence, the fifth hypothesis is proposed as H5 (+): Awareness of Behavior Control has a direct positive effect on customer's online shopping decision. 


\section{RESEARCH METHOLODY}

\section{Research sample}

In order to collect data to assess the measurement and test hypotheses, a questionnaire survey is designed for this research. Items adopted in previous well-established studies in Asian countries. The reason is the similarities of Vietnam and other Asian countries in cultural, behavioral and demographic characteristics. A pilot test with 30 samples to ensure the feasibility of the model and questionnaire [44]. Pilot tests can check errors and add tests to complete the official survey [45]. The questionnaire is translated into Vietnamese to ensure that respondents fully understand the content of the questionnaire. Four hundred samples were sent out and returned. However, 54 questionnaires were rejected because of missing information and 346 were used for further research. Perceived Usefulness (H1) includes six questions about the perceived usefulness of e-commerce and online shopping. Useful things include saving time, product variety, saving money, easy shopping anywhere. According to [46], the attitude of customers will be positive when they witness the selling price of products on websites is lower than that in traditional stores. Perceived Ease of Use (H2) includes five questions related to using e-commerce websites. Consumers appreciate the speed and effective responsiveness of online services [32]. The stages in the e-commerce website usage process include access, product search, ordering, and payment. Perceived Risk (H3) includes seven questions focusing on three main issues including information security and security when online transactions and products are not adequately described. According to [31], security has a direct impact on customer confidence when using online services. Perceived risk's problems have a negative impact on the decision to use the service. Social Influence (H4) includes five specific situations that directly affect customer behavior. Consumer decisions are the result of social impacts [36]. The impact comes from relatives, friends, and colleagues. Meanwhile, ssocial norms make consumer attitudes change when shopping online[37]. Awareness of Behavior Control (H5) reflects the ability to control behavior dramatically affects the decision to buy online. Attitudes have a direct impact on online shopping [40]. Ambience conditions also play a significant role in customer decisions. Also, knowledge is reported to have a positive relationship with trust and online shopping activities [43].

\section{Operationalization of variables}

Independent variables are Perceived usefulness, Perceived Ease of Use, Perceived risk, Social influence and Awareness of behavior control. The dependent variable is the awareness of decision making of online shopper (ADM). Independent variables are measured by Likert 5-point to measure buyer's perceptions with $1=$ totally disagree; $3=$ neither disagree or agree; $5=$ totally agree. Items are adopted from previous studies [19]

\section{Analysis procedure}

Cronbach' $\alpha$ and Exploratory Factor Analysis (EFA) are applied in this study by using SPSS to test reliability, validity, and fitness of the research model. Subsequently, the EFA is used to test the hypotheses. Finally, statistics on the model fit will be reported. The relationship between Perceived Usefulness, Perceived Ease of Use, Perceived Risk, Social Influence and Awareness of Behavior Control with online shopper's decision is presented in table 2: Regression Results. Then, the confirmation of the proposed hypothesis is clearly stated, and the last part is the result discussion and managerial implications.

\section{RESULTS AND DISCUSSION}

\subsection{Reliability and Validity Test} in table 1 .

The results of Cronbach's $\alpha$ test showed that all measurements achieve internal consistency $(\alpha>0.7)$

Table 1. Reliability Analysis

\begin{tabular}{|l|l|l|}
\hline Determinants & No. of items & Cronbach' $\boldsymbol{\alpha}$ \\
\hline Perceived Usefulness (PCU) & 6 & 0.815 \\
\hline Perceived Ease of Use(EOU) & 5 & 0.815 \\
\hline
\end{tabular}




\begin{tabular}{|l|l|l|}
\hline Perceived Risk(PCR) & 7 & 0.865 \\
\hline Social Influence( & 5 & 0.847 \\
\hline Awareness of Behavior Control & 5 & 0.761 \\
\hline
\end{tabular}

$\mathrm{KMO}$ coefficient is 0.814 with sig. $=0.000$ confirms the appropriateness of applying EFA in this survey.

\subsection{Hypotheses Testing}

The hypotheses are validated by the regression method. It can be seen that the results show that the variables are valid, where Perceived risk is the only variable that has a negative impact (-). F-value shows that models and independent variables ensure reliability and usability. $\mathrm{R}^{2}=0.561$ mean the linear model is explained by 56.1 percentage of the response variable variation. The results are shown in Table 2.

Table 2. Regression Results

\begin{tabular}{|l|l|l|}
\hline DV: ADM (Awareness of decision making) & t & Beta \\
\hline (Constant) & -.382 & \\
\hline PU & 7.831 & $.324^{*}$ \\
\hline PEU & 7.380 & $.323^{*}$ \\
\hline PR & -3.699 & $-.152^{*}$ \\
\hline SI & 8.083 & $.318^{*}$ \\
\hline ABC & 5.499 & $.225^{*}$ \\
\hline F-value $(d f 1, d f 2)$ & $\mathrm{F}(5.310)=79.171$ \\
\hline $\mathrm{R}^{2}\left(\right.$ Adjusted $\left.\mathrm{R}^{2}\right)$ & $0.561(0.554)$ \\
\hline Note: $* \mathrm{p}<0.01 ; * * \mathrm{p}<0.05, * * * \mathrm{p}<0.10$ & \multicolumn{2}{|l}{} \\
\hline
\end{tabular}

\subsection{Discussion and Implications}

Table 3. shows the results of hypothesis testing and findings are subsequently discussed.

\begin{tabular}{|l|c|}
\hline $\begin{array}{l}\text { H1: Perceived usefulness (PU) has a positive effect on customer's online } \\
\text { shopping decision. }\end{array}$ & Supported \\
\hline $\begin{array}{l}\text { H2: Perceived ease of use (PEU) has a positive effect on customer's online } \\
\text { shopping decision. }\end{array}$ & Supported \\
\hline $\begin{array}{l}\text { H3: Perceived risk (PR) has a negative effect on customer's online shopping } \\
\text { decision. }\end{array}$ & Supported \\
\hline $\begin{array}{l}\text { H4: Social influence (SI) has a direct positive effect on customer's online } \\
\text { shopping decision. }\end{array}$ & Supported \\
\hline $\begin{array}{l}\text { H5: Awareness of Behavior Control (ABC) has a direct positive effect on } \\
\text { customer's online shopping decision. }\end{array}$ & Supported \\
\hline
\end{tabular}

As being summarised above, PU $(\beta=0.324, \mathrm{p}<0.01)$ is founded to have a positive effect on customer's online shopping decision. Hence, the first hypothesis H1 is supported, and PU is the strongest determinant which has impacts on customer's decision in this study. This finding is consistent with many previous studies [19], [22]. Vietnamese online vendors should be interested in developing useful products and services to attract more customers [22]. Customers tend to make a purchase when the service provider supports home shipping or free delivery [19]. Moreover, in order to increase perceived usefulness of Vietnamese customers, business managers should provide comprehensive product information, fast order processing, price comparison tools and product review [17],[47]. As a result, the utilities of online shopping platforms will significantly encourage Vietnamese customer to have more and more transaction online.

PEU $(\beta=0.323, p<0.01)$ is reported to have a positive effect on the customer's online shopping decision. The second hypothesis is also supported, and it is consistent with other studies [19] [22]. The massive variety of online products may confuse customer during the shopping process. To encourage 
Vietnamese customer shop online more, business managers should improve customer experience via customer support services. According to Zhou [17], businesses can build customer loyalty by personalizing their shopping experience based on customer preferences and behavior. For example, businesses can suggest new products and brands which base on customer's preferences. Hence, it can help customers shop online easier. The interface of e-commerce websites should be user-friendly.

Moreover, graphic designs for website layout, mobile applications, and product placement can help customers quickly decide to participate in the experience and decide to purchase online [48]. For advertising purposes, e-commerce websites require customers to provide personal information before shopping. Many customers are unhappy about this, and businesses should reduce this step by linking accounts with third parties [49] so customer's perception on ease of using e-commerce platforms can be significantly improved.

Remarkably, $\operatorname{PR}(\beta=0.323, p<0.01)$ is founded to have a negative relation with customer's online shopping decision. Therefore, it is evident to conclude that $\mathrm{H} 3$ is accepted. Perceived risk is found to have negative impacts on an online shopper in many previous studies [23],[30], [50]. Online shopping customers tend to delay online shopping behavior when perceiving high risks [51]. Besides, recognizing risks has a negative impact on the development potential of e-commerce [52]. In order to reduce the perceived risk of online shopping, e-commerce platforms in Vietnamese must implement risk management systems to secure online transactions. For example, the online business can offer third-party intermediary payment services is an essential solution in the e-commerce industry [22]. There are many providers of payment information encryption services in Vietnamese markets such as PayPal, MasterCard, Samsungpay, Momo E-purse, and Viettelpay.

Furthermore, to reduce perceived risk among Vietnamese customers, e-commerce platforms should provide a comprehensive customer support system. Support channels such as call center, email, online support center can help customers notify business if they are aware of any risk during the online transaction process. Besides, the online shopping service provider should timely communicate with customers with specific product information, time and place for delivery to ensure the security of the delivery process. Vietnamese e-commerce flatforms also need to secure their database to avoid leaking of confidential information regarding a customer's identity. Customer's confidentiality should be the top priority for business to convince the customer to put their trust in online shopping services[40]. Chellappa and Pavlou [53] confirm that the security of internal enterprise systems needs to be encrypted and certified by security companies and governments.

SI $(\beta=0.323, p<0.01)$ is proven to have a positive impact on customer's online shopping decision. Therefore, the $\mathrm{H} 3$ hypothesis is supported. There are many studies confirm the importance of social influence on online shopping activities [39] [40]. To improve the positive effects of social influences, ecommerce platforms in Vietnam should pay more attention to branding. Huan [49] report that brands can attract and convince online shopping customers. Word-of-mouth marketing also can help Vietnamese business managers to improve positive social influences over online customers. An e-commerce platform with famous brands, excellent product quality, and attentive service is always prioritized by potential customers. The quality of service is what customers care about most when they decide to shop online via an e-commerce platform [47],[54], [55]. Furthermore, a website's interface should fit the customer experience [56]. Websites that have a friendly interface with people are always supported and introduced by customers to relatives and friends. From another perspective, business managers should not only focus on customers, but they should also focus on their loved ones [57]. Online business can attract new customer by offering current customer's relatives with referral incentives or group discounts. Hence, social influence can encourage more people to shop online via e-commerce platforms in Vietnam.

Lastly, $\mathrm{ABC}(\beta=0.323, \mathrm{p}<0.01)$ confirm a positive effect on customer's online shopping decision. The fifth hypothesis (H5) of this study is supported. This finding is consistent with many previous studies which report a positive relationship between Awareness of Behavior Control and online shopping behavior [19], [58], [59]. In order to improve customer's perceived behavior control, online business should provide assisting programs for Vietnamese customers in term of resources, ability, and knowledge of online shopping activities. For resources' support, e-commerce platforms in Vietnam should provide more financial flexibility such as credit payment, pay by installment or referring customers to third part's loans. As a result, online shoppers can perceive that they have enough financial resources to shop online via e- 
commerce platforms. Moreover, an online business also should do more advertising campaigns to equip potential customers with shopping skills to increase their's awareness of behavioral control. These skills can include order skill, tracking order delivery, payment skill, customer service inquiry skills and so on. Finally, e-commerce flatforms should provide more and more information about the conveniences and effectiveness of online shopping to potential customers in Vietnam. By doing so, Vietnamese online customers become more confident and keen on buying product and service via e-commerce platforms.

\section{Limitations and further research}

This study does not take into consideration the influences of demographic factors such as age, education, gender, income level into the research model. Hence, further research needs to address those demographic variables. For example, Susskind [60] confirm that education has a positive influence on online shopping decisions. The age that affects usage behavior, young people can always easily use online shopping services [61]. Meanwhile, older people often have a negative attitude like young people [2]. Income level also plays a big role in influencing customers' online shopping intent [60].Moreover, future research should also explore the effects of product characteristics, merchants and intermediate characteristics and environmental influences in online shopping behavior and enhance the predictive power of the proposed model. Social networks such as Facebook, Instagram, Zalo or Tiktok are prevalent and online merchants have utilized these social networks to sell their products to online customers. Therefore, future research should deep the influences of social networks on customer's online shopping decisions.

\section{REFERENCES}

[1] Ramachandran, K. K., Karthick, K. K., \& Kumar, M. S. (2011). Online shopping in the UK. International Business \& Economics Research Journal (IBER), 10(12), pp.23-36. Abbad, M., Abbad, R., \& Saleh, M. (2011). Limitations of e-commerce in developing countries: Jordan case. Education, Business and Society: Contemporary Middle Eastern Issues, 4(4), pp.280-291

[2] Donthu, N. and Garcia, A. (1999). The Internet Shopper. Journal of Advertising Research, 39( 3), pp.52-58.

[3] Satista (2018). E-commerce share of total global retail sales from 2015 to 2021. [online] Available at: https://www.statista.com/statistics/534123/e-commerce-share-of-retail-sales- worldwide/ [Accessed 05 Oct. 2018].

[4] Wen, C., Prybutok, V. R., \& Xu, C. (2011). An integrated model for customer online repurchases intention. Journal of Computer Information Systems, 52, pp.14-23.

[5] EVBN (2018). E-COMMERCE INDUSTRY IN VIETNAM REPORT, EDITION 2018. [online]

[6] Lohse, G. L., Bellman, S., \& Johnson, E. J. (2000). Consumer buying behavior on the Internet: Findings from panel data. Journal of Interactive Marketing, 14(1), pp.15-29

[7] VECITA (2014). VIETNAM MOBILE E-COMMERCE REPORT 2014. [online] Available at: http://www.moit.gov.vn/documents/20182/1577125/1508897514331-f7c2601c-17e9-4f2f-b6401bbfa1c5bcce.pdf?download=true [Accessed 08 Oct. 2018].

[8] VECITA (2014). VIETNAM MOBILE E-COMMERCE REPORT 2014. [online] Available at: http://www.moit.gov.vn/documents/20182/1577125/1508897514331-f7c2601c-17e9-4f2f-b6401bbfa1c5bcce.pdf?download=true [Accessed 08 Oct. 2018].

[9] Alba, J., Lynch, J., Weitz, B., Janizszewski, C., Lutz, R., Sawyer, A. and Wood, S. (1997). Interactive home shopping: Consumer, retailer, and manufacturer incentives to participate in electronic marketplaces. Journal of Marketing, 61 (3), pp.38-53. Available at: https://evbn.org/e-commerce-industry-in-vietnam-reportedition-2018/ [Accessed 08 Oct. 2018]. 
[10] Comegys, C., Hannula, M., \& Väisänen, J. (2006). Longitudinal comparison of Finnish and US online shopping behaviour among university students: The five-stage buying decision process. Journal of Targeting, Measurement and Analysis for Marketing, 14(4), pp.336-356.

[11]Darley, W. K., Blankson, C., \& Luethge, D. J. (2010). Toward an integrated framework for online consumer behavior and decision making process: A review. Psychology \& Marketing, 27(2), pp.94-116.

[12] Yörük, D., Dündar, S., Moga, L. M., \& Neculita, M. (2011). Drivers and Attitudes towards Online Shopping: Comparison of Turkey with Romania. Communications of the IBIMA, 2011, pp.1-12.

[13] Nguyen Thanh Do \& Ha Ngoc Thang (2014). Những cơ hội và thách thức của mua sắm trực tuyến ở Việt Nam. Science magazine - Hong Duc University, 20, pp.136-144.

[14] Lester, D. H., Forman, A. M., \& Loyd, D. (2005). Internet shopping and buying behavior of college students. Services Marketing Quarterly, 27(2), pp.123-138.

[15] Abbad, M., Abbad, R., \& Saleh, M. (2011). Limitations of e-commerce in developing countries: Jordan case. Education, Business and Society: Contemporary Middle Eastern Issues, 4(4), pp.280-291.

[16] Kolsar, M. B., \& Galbraith, R. W. (2000). A services-marketing perspective on e-retailing: implications for eretailers and directions for further research. Internet Research, 10(5), pp.424- 438.

[17]Zhou, L., Dai, L., \& Zhang, D. (2007). Online shopping acceptance model-A critical survey of consumer factors in online shopping. Journal of Electronic Commerce Research, 8(1), pp.41-62.

[18] Cheung, C., Chan, G. and Limayem, M. (2005), “A critical review of online consumer behavior: empirical research', Journal of Electronic Commerce in Organizations, Vol. 3 No. 4, pp. 1-19.

[19] Gong, T., et al. (2013). Customer Value Co-Creation Behavior: Scale Development and Validation. Journal of Business Research, 66(9), pp.1279-1284.

[20] Kocas, C. (2002). Evolution of prices in electronic markets under diffusion of price-comparison shopping. Journal of Management Information Systems, 19(3), 99-119.

[21]Moe, W. W., \& Schweidel, D. A. (2012). Online product opinions: Incidence, evaluation, and evolution. Marketing Science, 31(3), 372-386.

[22] Liu Xiao (2004). Empirical studies of consumer online shopping behavior. National university of Singapore.

[23] Ariffin, S., Mohan, T., \& Goh, Y. N. (2018). Influence of consumers' perceived risk on consumers' online purchase intention. Journal of Research in Interactive Marketing, 12(3), 309-327.

[24] Taylor S, Todd PA (1995). Understanding Information Technology Usage: A Test of Competing Models, Information Systems Research.

[25] Ramayah, T., (2008). Impact of Perceived usefulness, Perceived ease of use and Perceived Enjoyment on Intention to shop online. ICFAl Journal of Systems Management (USM), 3(3), pp.36-51.

[26] Teck, T.K. (2002). The Impact of Perceived Web Security . Perceived Privacy Loss , Perceived Usefulness and Perceived Ease of Use on the Web - Based Online Transaction Intent. MBA Thesis, School of Management.

[27] Davis, D. Fred, and Arbor, Ann. (1989). Perceived Usefulness, Perceived Ease of Use, and User Acceptance of Information Technology. MIS Quarterly, 13(3), pp.319-39.

[28] Juniwati (2014). Influence of Perceived Usefulness, Ease of Use, Risk on Attitude and Intention to Shop Online. European Journal of Business and Management, 6(27), pp.218-228. 
[29] Seiders, K, \& Grewal, D (2002). Understanding Service Convenience. Jounal of Marketing, 66(3), pp.1-17.

[30] Forsythe, S., Liu, C., Shannon, D., \& Gardner, L. C. (2006). Development of a scale to measure the perceived benefits and risks of online shopping. Journal of interactive marketing, 20(2), 55-75.

[31] Gitau, L. and Nzuki, D. (2014). Analysis of Determinants of M-Commerce Adoption by Online Consumers. International Journal of Business, Humanities and Technology, 4(3), pp.88-94.

[32] Jiang, L., Yang, Z., (2013). Measuring consumer perceptions of online shopping convenience. Journal of Service Management, 24(2), pp.191-214.

[33] Grandinetti, M. (1996). Establishing and maintaining security on the Internet. Sacramento Business Journal, $13(25)$, pp. 22.

[34]Zorkadis, V., Karras, D.A. (2000). Security modeling of electronic commerce infrastructures. Information Systems for Enhanced Public Safety and Security, IEEE/AFCEA (5), pp.340-344.

[35] Ajzen I., Fishbein M. (1975), Belief, Attitude, Intention, and Behavior: An Introduction to theory and research, Addition-Wesley, Reading, MA.

[36] Ha. S. and Stoel, L. (2009). Consumer e-shopping acceptance: Antecedents in a technology acceptance model. Joumal of Business Research, 62(5), pp.565-571.

[37] Barkh, R, Belanger, F., \& Hicks, J. (2008). A model of the determinants of purchasing from virtual stores. Journal of Organizational Computing \& Electronic Commerce, 183, pp.177-196.

[38] Chin, A. J., Wafa, S. A. W. S. K., \& Ooi, A. Y. (2009). The effect of internet trust and social influence towards willingness to purchase online in Labuan, Malaysia. International Business Research, 2(2), 72-81.

[39]Zhao, K., Stylianou, A. C., \& Zheng, Y. (2018). Sources and impacts of social influence from online anonymous user reviews. Information \& Management, 55(1), 16-30.

[40]Limayem, M, Khalifa, M \&Chin (2004). Factors motivating software piracy: A longitudinal study. IEEE Transactions on Engineering Management, 51(4), pp.414-425.

[41] Jarvenpaa, S.L., Tractinsky, N. and Vitale, M. (1999), “Consumer trust in an internet store', Information Technology and Management, 1(12), pp.45-71.

[42] Maghrabi, T., Dennis, C., and Halliday, S. V (2011). Antecedents of continuance intentions towards e shopping: The case of Saudi Arabia. Journal of Enterprise Information Management, 24(1), pp.85-111.

[43] Wang, C. C., Chen, C. A., \& Jiang, J. C. (2009). The Impact of Knowledge and Trust on E-Consumers' Online Shopping Activities: An Empirical Study. JCP, 4(1), 11-18.

[44] Van Teijlingen ER, Hundley V (2001). The Importance of Pilot Studies. Social Research Update, pp.35.

[45]Lancaster GA, Dodd S, Williamson PR (2004). Design and analysis of pilot studies: recommendations for good practice. J Eval Clin Pract, 10, pp.307-312.

[46]Foley, P, \&Sutton, D. (1998). The potential for trade facilitated by the Internet 1996-2000: A review of demand, supply and Internet trade models. In R. W. Blanning \& D. R. King (Eds.), Proceedings of the 31st Annual Huwai International Conference on System Sciences, 4, pp.210- 221.

[47] Black, N.J., Lockett, A., Ennew, C., Winklhofer, H. and McKechnie, S. (2002). Modeling consumer choice of distribution channels: an illustration from financial services. International Journal of Bank Marketing, 20(4), pp.161-173. 
[48] Hansen, T (2005). Consumer adoption of online grocery buying: a discriminant analysis. International Journal of Retail \& Distribution Management, 33( 2/3), pp.101- 21.

[49] Huan, W, Schrank, H,\&Dubinsky, A. (2004). Eiect of brand name on consumers risk perceptions of online shopping. Journal of Consumer Behavior, pp.0-50.

[50]Folarin, T. O., \& Ogundare, E. A. INFLUENCE OF CUSTOMERS'PERCEIVED RISK ON ONLINE SHOPPING INTENTION IN MALAYSIA'S APPAREL INDUSTRY.

[51] Monsuwe, T. P. y., Dellaert, B., G. C., \& Ruyter, K. d. (2004). What drives consumers to shop online? A literature reviews. International Journal of Service Industry Management, 15(1), pp.102-121.

[52] Suki, N. (2007). ONLINE BUYING INNOVATIVENESS: EFFECTS OF PERCEIVED

[53] Chellappa, R. K., \& Pavlou, P.A. (2002). Perceived information security, financial liability and consumer trust ir leetronie commerce transactions. Logistics information management, 5(5/6), pp.358- 368.

[54] Santos, J. (2003). E-service quality: A model of virtual service quality dimensions. Managing Service Quality, 13(3), pp.233.

[55] Yang, Z., \& Jun, M. (2002). Consumer perception of e-service quality: from internet purchaser and nonpurchaser perspectives. Journal of Business Strategies, 19(1), pp.19-41.

[56] Li, D., Browne, G.J. and Wetherbe, J.C. (2006). Why do internet users stick with a specific web site? A relationship perspective. International Journal of Electronics Commerce, 10(4), pp.105-141.

[57] Allred, Scott M. Smith, William R. Swinyard, (2006). "E-shopping lovers and fearful conservatives: a market segmentation analysis", International Journal of Retail \& Distribution Management, 34(4/5), pp.308-333.

[58] Vermeir, Iris, and Wim Verbeke (2006). Sustainable Food Consumption: Exploring the Consumer 's Attitude Behavioral Intention' Gap. Journal of Agricultural and Environmental Ethics, 19, pp.169-194.

[59] Gong, W., Stump, R. L., \& Maddox, L. M. (2013). Factors influencing consumers' online shopping in China. Journal of Asia Business Studies, 7(3), 214-230.

[60] Susskind, A. (2004). Electronic commerce and world wide web apprehensiveness: An examination of consumers' perceptions of the world wide web. Journal of Computer-Mediated Communication, 9(3).

[61] Stafford, T. F., Turan, A., \& Raisinghani, M. S. (2004). International and cross-cultural influences on online shopping behavior. Journal of Global Information Technology Management, 7(2), 70-87.

Received on February ${ }^{\text {st }}$, 2019

Accepted on March 25 th 2019 